\title{
Incidence of epithelial lesions of the conjunctiva in a review of 12,102 specimens in Canada (Quebec)
}

\author{
Incidência de lesões epiteliais da conjuntiva em revisão de 12.102 casos no Canadá (Quebec) \\ Luiz Filipe de Albuquerque Alves ${ }^{1,2,3}$, Bruno Franco Fernandes² ${ }^{2}$ Julia Valdemarin Burnier², Pablo Zoroquiain², Demian Temponi Eskenazl², \\ Miguel Noel Burnier JR²
}

\section{ABSTRACT}

Purpose: The purpose of this study was to assess the relative frequency of epithelial lesions of the conjunctiva in Canada.

Methods: A retrospective study of 12,102 consecutive cases received during 16 years (1993-2009) at the Henry C. Witelson Ocular Pathology Laboratory in Montreal, Canada, was performed. Demographic data was retrieved from histopathological request forms and specimens were categorized and analyzed by mean percentage. The relative frequency of epithelial lesions of the conjunctiva from a single center in Canada, representing the province of Quebec was reviewed.

Results: Of the 12,102 specimens reviewed, 273 were conjunctival lesions (2.25\%), including 86 epithelial tumors $(0.71 \%)$ of the conjunctiva that comprised the studied sample. The average age of these patients was $59.9 \pm 17.6$ years, and gender distribution was 66 (69\%) males and 30 (31\%) females. Fifteen lesions (17.4\%) were classified as squamous cell papillomas (mean age, $57.3 \pm 16.7$ years). Within the ocular surface squamous neoplasia (OSSN) spectrum, there were 10 (11.6\%) actinic keratosis $(63.8 \pm 17.6$ years), 27 (31.3\%) cases of conjunctival intraepithelial neoplasia (CIN) with variable degrees of atypia (mild to moderate) (63.9 \pm 15.3 years), 15 (17.4\%) carcinomas in situ (66.7 \pm 18.0 years), and 17 (19.7\%) squamous cell carcinomas (SCC) (56.2 \pm 19.4 years). Two other rare cases of malignant tumors included one basal cell carcinoma and one mucoepidermoid carcinoma.

Conclusions: The distribution of our sample is similar to the one reported by the American Forces Institute of Pathology (AFIP) in 1994. When we compare our sample to others coming from countries with high levels of sunlight exposure, we found a lower incidence of ocular surface squamous neoplasia, including squamous cell carcinomas in Canada.

Keywords: Conjunctiva/pathology; Conjunctival neoplasms/epidemiology; Eye neoplasms/pathology; Corneal diseases/pathology; Carcinoma in situ; Carcinoma, squamous cell; Canadá/epidemiology

\section{RESUMO}

Objetivo: 0 estudo realizado teve como objetivo fornecer a relativa frequência de cada lesão epitelial de conjuntiva no Canadá.

Métodos: Trata-se de estudo retrospectivo de todos os casos recebidos durante 16 anos (1993-2009) no Henry C. Witelson Ocular Pathology Laboratory, em Montreal. Dados epidemiológicos foram obtidos por meio de requerimento e laudos histopatológicos, sendo classificados e analisados pelo porcentual na amostra. A relativa frequência de lesões epiteliais da conjuntiva foram obtidas em um único centro de análises no Canadá.

Resultados: Entre 12.102 espécimes revisadas, 273 foram lesões conjuntivais (2,25\%), sendo 86 tumores epiteliais $(0,71 \%)$ entre a amostra estudada. A idade média das lesões neoplásicas da conjuntiva foi de 59,9 \pm 17,6 anos, e a distribuição por sexo foi de 66 (69\%) homens e 30 (31\%) mulheres. Quinze lesões $(17,4 \%)$ foram classificadas como papilomas de células escamosas (idade média 57,3 $\pm 16,7$ anos). No grupo das neoplasias escamosas da superfície ocular (NESO) foram encontrados $10(11,6 \%)$ casos de queratose actínica, (63,8 $\pm 17,6$ anos), 27 (31,3\%) casos de neoplasia intraepitelial (NIC), com moderada atipia (63,9 $\pm 15,3$ anos), 15 (17,4\%) carcinomas in situ (66,7 $\pm 18,0$ anos), e 17 (19,7\%) carcinomas de células escamosas (CCE) (56,2 $\pm 19,4$ anos). Dois outros casos menos frequentes de tumores malignosforam incluídos; um carcinoma de célula basal e outro carcinoma mucoepidermoide.

Conclusão: A distribuição de nossa amostra é semelhante a encontrada no Armed Forces Institute of Pathology (AFIP) em 1994, porém quando comparamos nossa amostra com estudos realizados em países com altos níveis de exposição solar observamos menor incidência de neoplasias escamosas da superfície ocular, incluindo-se carcinomas de células escamosas.

Descritores: Conjuntiva/patologia; Neoplasias da túnica conjuntiva/epidemiologia; Neoplasias oculares/patologia; Doenças da córnea/patologia; Carcinoma in situ; Carcinoma de células escamosas; Canadá/epidemiologia

\section{INTRODUCTION}

$\mathbf{N}$ onmelanocytic lesions represent $47 \%$ of all excised conjunctival tumors ${ }^{(1)}$. Epithelial lesions of the conjunctiva comprise a large variety of conditions, from benign tumors such as papilloma, to malignant lesions such as squamous cell carcinoma (SCC) (2). Ocular surface squamous neoplasia (OSSN) is a recent term that categorizes precancerous and malignant lesions, including

\footnotetext{
Work carried out at the Henry C. Witelson Ocular Pathology Laboratory in Montreal, Canada. ${ }^{1}$ Department of Ophthalmology, Brazilian Air Force Central Hospital Rio de Janeiro, Rio de Janeiro (RJ), Brazil.

2 Department of Ophthalmology and Pathology, The McGill University Health, Center \& Henry C. Witelson Ocular Pathology Laboratory. Montreal, Canada.

${ }^{3}$ Department of Ophthalmology. Universidade Federal de São Paulo - UNIFESP - São Paulo (SP), Brasil. Correspondence address: Luiz Filipe de Albuquerque Alves. 3775 University Street, room 216, Montreal, Quebec - Canada - H3A-2B4 - Email: filipeoftalmo@globo.com

Recebido para publicação em 03.03.2010

Última versão recebida em 06.11.2010

Aprovação em 25.11.2010
}

conjunctival intraepithelial neoplasia (CIN) and SCC ${ }^{(3-4)}$. Epithelial lesions are the second most common group of conjunctival specimens. Distribution is affected by geography, sunlight exposure and other factors such as human immunodeficiency virus (HIV) and human papilloma virus (HPV) prevalence. OSSN is found in all demographics, with a higher incidence in males ${ }^{(4)}$. According to the Institute of Ophthalmology in England ${ }^{(5)}$, the Brazilian Registry ${ }^{(6)}$ and the American Forces Institute of Pathology (AFIP) Registry ${ }^{(6)}$, epithelial tumors account for one third to half of conjunctival neoplasms $s^{(1,7)}$.

The purpose of the present study was to assess the relative frequency of each epithelial lesion of the conjunctiva in Canada and to analyze possible correlations of etiology agents in the samples.

\section{METHODS}

A retrospective study was performed using 12,102 consecutive cases received during 16 years (1993-2009) at the Henry C. Witelson Ocular Pathology Laboratory, Montreal, Canada. Demographic data, age at diagnosis and gender were retrieved from histopathological request forms. 
Specimens were categorized and analyzed by mean percentage. Data accumulation was acquired in accordance with country and provincial laws and the tenets of the Declaration of Helsinki.

\section{RESULTS}

Of the 12,102 specimens, 273 were conjunctival lesions (2.25\%), including 86 epithelial tumors $(0.71 \%)$ of the conjunctiva. The average age was $59.9 \pm 17.6$ years, and gender distribution was 66 (69\%) males and 30 (31\%) females (Table 1).

Fifteen lesions (17.4\%) were classified as squamous cell papillomas (mean age, $57.3 \pm 16.7$ years). Within the OSSN spectrum, there were 10 (11.6\%) actinic keratosis (63.8 \pm 17.6 years), 27 (31.3\%) cases of CIN with variable degrees of atypia (moderate dysplasia) $(63.9 \pm 15.3$ years), 15 (17.4\%) carcinoma in situ (66.7 \pm 18.0 years), and $17(19,7 \%)$ SCC (56.2 \pm 19.4 years). Two other cases of malignant tumors included one basal cell carcinoma and one mucoepidermoid carcinoma (Table 2).

\section{DISCUSSION}

Ocular surface squamous neoplasia comprises dysplasia, carcinoma in situ and squamous cell carcinoma involving the conjunctiva as well as the cornea ${ }^{(8)}$. Most commonly OSSN arises in the limbal region, occurring particularly in elderly males, it is found in demographics, but is more common in countries that have a higher level of sunlight exposure.

The main etiological factors that are associated with epithelial lesions of conjunctiva include sunlight exposure, HPV subtypes 6,11,16 and 18 and HIV(4). Many other risk factors for the development of OSSN have been suggested, such as chronic inflammatory diseases. OSSN has also been associated with benign mucous membrane pemphigoid ${ }^{(9)}$, chronic blepharoconjunctivitis ${ }^{(10)}$, vitamin A deficiency and, in one case, atopic eczema ${ }^{(11)}$. OSSN has been associated with pinguecula and pterygium ${ }^{(12)}$ due to the fact these conditions are important differential diagnoses in establishing OSSN. Studies have reported OSSN in patients with leukemia ${ }^{(13)}$, lympho-

Table 1. Specimens in Canada, Quebec (1993-2009)

\begin{tabular}{lccccc}
\hline & $\begin{array}{c}\text { Cases } \\
(\mathbf{\%})\end{array}$ & $\begin{array}{c}\text { Avg. } \\
\text { Age }\end{array}$ & STD & $\begin{array}{c}\text { Male } \\
(\mathbf{\%})\end{array}$ & $\begin{array}{c}\text { Female } \\
(\mathbf{\%})\end{array}$ \\
\hline $\begin{array}{l}\text { Total sample } \\
\text { Tumors of }\end{array}$ & $12,102(100)$ & & & & \\
$\begin{array}{l}\text { conjunctiva } \\
\text { Epithelial tumors }\end{array}$ & $273(2.25)$ & 59.9 & \pm 17.6 & $66(69)$ & $31(31)$ \\
\hline
\end{tabular}

Table 2. Epithelial tumors of the conjunctiva

\begin{tabular}{lccc}
\hline & Cases (\%) & Avg. Age & STD \\
\hline $\begin{array}{l}\text { Benign } \\
\quad \text { Papillomas }\end{array}$ & $15(17.4)$ & 57.3 & \pm 16.7 \\
Intraepithelial neoplasia & & & \\
$\quad$ Actinic keratosis & $10(11.6)$ & 63.8 & \pm 17.6 \\
$\quad$ Dysplasia & $27(31.3)$ & 63.9 & \pm 15.3 \\
Carcinoma in situ & $15(17.4)$ & 66.7 & \pm 18.0 \\
Malignant & $17(19.7)$ & 56.2 & \pm 19.4 \\
$\quad$ SCC & 2 & & \\
Other types & 86 & & \\
Total & & & \\
\hline
\end{tabular}

Frequency distribution of 86 specimens of tumors in McGill University Health Center $\mathrm{ma}^{(14)}$, and following liver transplantation ${ }^{(15)}$. Others factors, such as cigarette smoking, petroleum products, European ancestry ${ }^{(16)}$, chronic use of contact lens ${ }^{(17)}$ and cyclosporine A have been proposed for the development of OSSN. In addition, children with xeroderma pigmentosum are more likely to develop SCC due to the high degree of sensibility to sunlight ${ }^{(18-19)}$

The overall incidence of OSSN ranges from 0.02 to 3.5 per 100,000 per year worldwide. In the United States (National Institute of Health study), Australia(20), and Uganda (21), the incidence of OSSN are $0.03,1.9$ and 0.13 cases per 100,000 persons, respectively. OSSN of the ocular surface was found to be the most common in Zimbabwe ${ }^{(22)}$. As the cases analyzed here come from a single ocular pathology lab in Montreal, Quebec, it cannot be used to represent incidence in Canada In most studies, a higher prevalence of OSSN has been found in males ${ }^{(23-24)}$ which can be explained by the greater exposure of males to sunlight while working outdoors. in contrast, a study performed in Zimbabwe ${ }^{(22)}$, concluded that $70 \%$ of the patients with OSSN were female. This can be explained, however, that Zimbabwean women spend more time in cultivation and are more exposed to the sunlight than men. In addition, several studies have shown a predominance of OSSN in Caucasians due to the greater predisposition of fair skinned people to UV-related skin damage(25). However, darker skinned populations that live in tropical regions are more exposed to sunlight and have a higher incidence of OSSN. For that reason, Caucasian populations living at latitudes less than $30^{\circ}$ to the equator have a particularly higher risk for developing OSSN $(3,26)$. In fact, Newton et al.(27) found that the incidence of SCC of the eye increases $49 \%$ with each 10 -degree decline in latitude.

The results of several studies have shown the average age of OSSN is 56 years of age ${ }^{(3)}$. Some author ${ }^{(26)}$ noted the age of onset of populations living at latitudes less than $30^{\circ}$ to the equator was younger than at latitude $45^{\circ}$ (53 years vs. 64 years). The youngest case reported was a 4-year-old Caucasion female who developed an inferior palpebral conjunctival lesion one year after strabismus surgery ${ }^{(28)}$. The second younger group of cases are in children with xeroderma pigmentosum ${ }^{(29)}$. According to previous studies the average age of patients with carcinoma in situ is 5-9 years less than patients of invasive squamous cell carcinoma ${ }^{(30)}$. These studies suggest that precancerous CIN may progress to invasive SCC.

The most common benign tumor in our center was squamous papilloma (17.4\%). Patients with benign lesions comprised the youngest average group. Surprisingly, however, patients with malignant lesions (19.7\%) were on average younger than those with premalignant (80.2\%) lesions. In fact, the group representing the oldest average age was found to be patients presenting with carcinoma in situ (Table 2). The youngest case found was a 12-yearold who developed SCC with orbital invasion, however the number of SCCs in our sample was not sufficient to significantly prove the tendency to develop SCC at a lower average age in Canada (Table 3). In this particular study, the three youngest cases included the 12 year old previously mentioned as well as two cases of 34year-old patients with SCC, and these cases may present outliers to the normal distribution of age-related incidence. However, due to the small sample size, these cases decreased the average age of incidence in this particular group. It can be speculated that the fact that Canada presents lower level of sunlight exposure, others etiologic factors could be more relevant in our sample, making sunlight exposure leading to the progression of carcinoma in situ (CIS) to SCC less relevant. For this reason, according to our data, the lower mean age of SCC could indicate a different mechanism of developing malignant tumors such as involvement of HPV, HIV, chronic inflammations or others etiologic factors.

Overall, our data are in agreement with results of previous studies of North American populations including the AFIP in 1994(6), Lee et al., in 1992 ${ }^{(20)}$ and Locke ${ }^{(31)}$ (Table 3) and all literature reviewed. Conversely, when we compare our sample to studies performed in 
Table 3. Epidemiology of epithelial lesions of conjunctiva

\begin{tabular}{lcccccc}
\hline & Total & Benign (\%) & CIN (\%) & CIS (\%) & SCC (\%) & Age mean OSSN \\
\hline Canada, 1993-2009 & 86 & $15(17.4)$ & $37(43.0)$ & $15(17.40)$ & $19(22.0)$ & 60 \\
USA AFIP, 1984-1989(6) & 509 & $97(19.0)$ & $225(44.2)$ & $26(5.10)$ & $161(31.6)$ & - \\
${ }^{*}$ Australia ${ }^{(3)}$ & 288 & - & $155(53.8)$ & $71(24.60)$ & $62(21.5)$ & 60 \\
USA, Erie et al., 1986(32) $_{\text {Africa, Clear et al., 1979(33) }}^{120}$ & 216 & - & $98(81.6)$ & - & $22(18.3)$ & 62 \\
\hline
\end{tabular}

$\mathrm{CIN}=$ conjunctival intraepithelial neoplasia, $\mathrm{CIS}=$ carcinoma in situ, SCC= squamous cell carcinoma, OSSN= ocular surface squamous neoplasia

${ }^{*}=$ Australia apud ${ }^{(3)}$

countries with higher levels of sunlight exposure, we found a lower percentage of OSSN, including SCC in Canada.

In summary, to the best of our knowledge, the present work represents the largest series report of OSSN tumors in Canada. In addition, we review some of the important etiological factors involved in the development of epithelial lesions of the conjunctiva. By comparing our data to other reports in various countries, we found a lower relative proportion of OSSN cases within all conjunctival lesions, which can be plausibly explained by differences in sunlight exposure. Documenting the distribution of various epithelial lesions and their relative proportion, as has been done here, is essential for early diagnosis, preventative care, and for better understanding the natural history of these diseases.

\section{REFERENCES}

1. Shields CL, Demirci H, Karatza E, Shields JA. Clinical survey of 1643 melanocytic and nonmelanocytic conjunctival tumors. Ophthalmology. 2004;111(9):1747-54.

2. Ogun GO, Ogun OA, Bekibele CO, Akang EE. Intraepithelial and invasive squamous neoplasms of the conjunctiva in Ibadan, Nigeria: a clinicopathological study of 46 cases. Int Ophthalmol. 2009;29(5):401-9.

3. Lee GA, Hirst LW. Ocular surface squamous neoplasia. Surv Ophthalmol. 1995; 39(6):429-50.

4. Pe'er J. Ocular surface squamous neoplasia. Ophthalmol Clin North Am. 2005;18(1):1-13, vii.

5. Garner A. The pathology of tumours at the limbus Eye (Lond). 1989;3(Pt2):210-7.

6. MacLean I, Burnier M, Zimmerman L, Jacobiec F. Tumors of the conjunctiva. In: Rosai J, editor. Tumors of the eye and ocular adnexa. Washington, DC: American Forces Institute of Pathology; 1994. p.41-91.

7. Novais GA, Fernandes BF, Belfort RN, Castiglione E, Cheema DP, Burnier MN, Jr. Incidence of melanocytic lesions of the conjunctiva in a review of 10675 ophthalmic specimens. Int J Surg Pathol. 2008;18(1):60-3.

8. Grossniklaus HE, Green WR, Luckenbach M, Chan CC. Conjunctival lesions in adults. A clinical and histopathologic review. Cornea. 1987;6(2):78-116.

9. Sivalingam V, Shields CL, Shields JA, Pearah JD. Squamous cell carcinoma of the conjunctiva associated with benign mucous membrane pemphigoid. Ann Ophthalmol. 1990;22(3):106-9.

10. Akpek EK, Polcharoen W, Chan R, Foster CS. Ocular surface neoplasia masquerading as chronic blepharoconjunctivitis. Cornea. 1999;18(3):282-8.

11. Heinz C, Fanihagh F, Steuhl KP. Squamous cell carcinoma of the conjunctiva in patients with atopic eczema. Cornea. 2003;22(2):135-7.

12. Degrassi M, Piantanida A, Nucci P. Unexpected histological findings in pterygium. Optom Vis Sci. 1993;70(12):1058-60.
13. Awan KJ. Intraepithelial epithelioma (Bowen's disease) of conjunctiva and chronic lymphocytic leukemia. Ann Ophthalmol. 1978;10(6):781-3.

14. Kushner FH, Mushen RL. Conjunctival squamous cell carcinoma combined with malignant lymphoma. Am J Ophthalmol. 1975;80(3 Pt 2):503-6.

15. Shelil AE, Shields CL, Shields JA, Eagle RC Jr. Aggressive conjunctival squamous cell carcinoma in a patient following liver transplantation. Arch Ophthalmol. 2003;121(2):280-2.

16. Moubayed P, Mwakyoma H, Schneider DT. High frequency of human papillomavirus 6/11, 16 , and 18 infections in precancerous lesions and squamous cell carcinoma of the conjunctiva in subtropical Tanzania. Am J Clin Pathol. 2004;122(6):938-43.

17. Whittaker KW, Trivedi D, Bridger J, Sandramouli S. Ocular surface squamous neoplasia: report of an unusual case and review of the literature. Orbit. 2002;21(3):209-15.

18. Chisi SK, Kollmann MK, Karimurio J. Conjunctival squamous cell carcinoma in patients with human immunodeficiency virus infection seen at two hospitals in Kenya. East Afr Med J. 2006;83(5):267-70

19. De Silva DJ, Tumuluri K, Joshi N. Conjunctival squamous cell carcinoma: atypical presentation of HIV. Clin Experiment Ophthalmol. 2005;33(4):419-20.

20. Lee GA, Hirst LW. Incidence of ocular surface epithelial dysplasia in metropolitan Brisbane. A 10-year survey. Arch Ophthalmol. 1992;110(4):525-7.

21. Templeton AC. Tumours of the eye and adnexa. Recent Results Cancer Res. 1973;41:203-14.

22. Pola EC, Masanganise R, Rusakaniko S. The trend of ocular surface squamous neoplasia among ocular surface tumour biopsies submitted for histology from Sekuru Kaguvi Eye Unit, Harare between 1996 and 2000. Cent Afr J Med. 2003; 49(1-2):1-4.

23. Lee GA, Hirst LW. Retrospective study of ocular surface squamous neoplasia. Aust N Z J Ophthalmol. 1997;25(4):269-76.

24. Cervantes G, Rodriguez AA Jr, Leal AG. Squamous cell carcinoma of the conjunctiva: clinicopathological features in 287 cases. Can J Ophthalmol. 2002; 37(1):14-9; discussion 9-20.

25. Ash JE. Epibulbar tumors. Am J Ophthalmol. 1950;33(8):1203-19.

26. Ni C, Searl SS, Kriegstein HJ, Wu BF. Epibulbar carcinoma. Int Ophthalmol Clin. 1982; 22(3):1-33.

27. Newton R, Ferlay J, Reeves G, Beral V, Parkin DM. Effect of ambient solar ultraviolet radiation on incidence of squamous-cell carcinoma of the eye. Lancet. 1996;347(9013): 1450-1.

28. IliffWJ, Marback R, Green WR. Invasive squamous cell carcinoma of the conjunctiva. Arch Ophthalmol. 1975;93(2):119-22.

29. Hertle RW, Durso F, Metzler JP, Varsa EW. Epibulbar squamous cell carcinomas in brothers with Xeroderma pigmentosa. J Pediatr Ophthalmol Strabismus. 1991;28(6):350-3.

30. Elsas FJ, Green WR. Epibulbar tumors in childhood. Am J Ophthalmol. 1975; 79(6):1001-7.

31. Locke JC. Bowen's disease (intraepithelial epithelioma) of the cornea and conjunctiva; a clinicopathologic study. Am J Ophthalmol. 1956;41(5):801-9.

32. Erie JC, Campbell RJ, Liesegang TJ. Conjunctival and corneal intraepithelial and invasive neoplasia. Ophthalmology. 1986;93(2):176-83.

33. Clear AS, Chirambo MC, Hutt MS. Solar keratosis, pterygium, and squamous cell carcinoma of the conjunctiva in Malawi. Br J Ophthalmol. 1979:63(2):102-9. 